\title{
Section I: Outer Space
}

\author{
Rule 1
}

For the purposes of this Manual:

(a) "Outer Space"

i. begins at the lowest possible point of the orbital perigee of artificial satellites;

ii. lies beyond the jurisdiction of all States.

\section{Commentary}

1. There is no general international agreement or customary international law specifying the precise definition and delimitation of Outer Space. The definition of "Outer Space" used in this Manual is consistent with current practice.

2. Outer Space with respect to jurisdictional arrangements is similar to the high seas.

3. At present, the lowest orbital perigee of satellites is approximately $100 \mathrm{~km}$ above sea level. ${ }^{1}$

\section{(b) The Moon and other Celestial Bodies}

i. do not include Earth.

ii. are separated by Outer Space but are not stricto sensu part of it.

\section{Commentary}

1. The Moon and other Celestial Bodies are generally considered res communis omnium. This implies that they are open for exploration, exploitation and use by

\footnotetext{
${ }^{1}$ As to the 100 kilometre approximation, see Program on Humanitarian Policy and Conflict Research at Harvard University, HPCR Manual on International Law Applicable to Air and Missile Warfare (AMW Manual) (2009), commentary Rule 1 (a) paragraph 5.
} 
States, whether individually or collectively. They are not subject to national appropriation, which means that sovereignty can not be excercised over them by way of occupation (the non-appropriation principle). ${ }^{2}$

2. The non-appropriation principle implies a freedom of movement where States can launch objects, including spacecraft into Outer Space in order to orbit Earth, the Moon or other Celestial Bodies without having to seek permission from other States as long as the launch trajectory does not transit the national airspace of another State without authorization.

3. On the responsibility of States for activities conducted by persons belonging to their armed forces, see Rule 5.

4. The primary interest recognized in the OST is the maintenance of international peace and security. ${ }^{3}$ See also Commentary to Rule 2.

(c) "Outer Space operations" are operations that employ capabilities aimed at achieving objectives in or through Outer Space.

\section{Commentary}

1. The phrase "Outer Space operations" is broadly defined in this Manual. ${ }^{4}$

2. Outer Space operations comprise activities where, for example, an object traverses temporarily through Outer Space as part of a ballistic trajectory, or where activities on Earth have effects in Outer Space, such as the launching of a satellite. Use of satellite signals on Earth, including for communication or navigation (including GPS and communication signals), is not an Outer Space operation. The jamming of a satellite is an Outer Space operation, whereas conventional jamming within airspace of a signal transmitted by a satellite is not.

3. Satellites send information via the electromagnetic spectrum, which is the collective term for all known frequencies of electromagnetic radiation and their linked photon wavelengths. The use of satellites can include the following categories: remote sensing, communications, scientific research and navigation. Most terrestrial use of satellite imagery, communication or navigation, however, does not constitute Outer Space operations as such.

(d) "Outer Space systems and assests" are those human-made systems and assets located in Outer Space as well as on the Moon and other Celestial Bodies, with or without human occupants. The phrase includes spacecraft, satellites and all related infrastructure (including up-links and down-links).

\footnotetext{
${ }^{2}$ Treaty on Principles Governing the Activities of States in the Exploration and Use of Outer Space, including the Moon and Other Celestial Bodies (OST) (1967), United Nations Treaty Series (UNTS), vol. 610, page 205. See Articles I and II.

${ }^{3}$ OST, ibid, Article III.

${ }^{4}$ OST, ibid, Articles VI and VII.
} 


\section{Commentary}

1. "Outer Space systems and assets" create the capabilities for Outer Space operations as defined in (c).

2. The definition of "Outer Space systems and assets" includes any or all component parts of the systems and assets as defined.

3. Examples are data and communication links, payloads, and ancillary devices and facilities such as:

a. Ground stations;

b. Ground station mission or user terminals, which may include initial reception, processing and exploitation terminals;

c. Launch systems and directly related support infrastructure, including space surveillance, battle management, command, control, and communications infrastructure and computers;

d. Launch sites;

e. Booster storage facilities;

f. Satellite storage and assembly facilities;

g. Telemetry, Tracking, and Commanding (TT\&C) nodes, including both hot and cold back up facilities;

h. Research and development facilities; and

i. Launch facilities and vehicles.

4. Manufacturing plants and assembly lines on Earth are generally excluded from the definition. However, exceptionally, all infrastructure essential for Outer Space operations, even if located on Earth, would be included.

\section{Rule 2}

Outer Space operations are governed by international law, including the Charter of the United Nations and the applicable principles and rules of the Law of Armed Conflict (LOAC).

\section{Commentary}

1. It has to be acknowledged that the degree of practice of States (as well as the state of opinio juris) leaves some doubt as to whether customary international law has already consolidated in so far Outer Space operations are concerned. However, in principle, all Outer Space operations are governed by the Charter of the United Nations. ${ }^{5}$

2. Article III of the Outer Space Treaty refers to the applicability in Outer Space of international law. The Group of Experts believes that the general reference to international law extends to LOAC. In view of the unique characteristics of Outer Space activities as such, in the absence of sufficient State practice and opinio

\footnotetext{
${ }^{5}$ Charter of the United Nations (1945), UNTS, vol. 1.
} 
juris, the application or interpretation of LOAC in Outer Space may be subject to controversy.

3. The OST ostensibly limits the use of Outer Space to "peaceful purposes" ${ }^{\prime 6}$ and the use of the Moon and other Celestial Bodies to "exclusively peaceful purposes". 7 This terminology is generally construed as proscribing only military operations that are carried out in breach of the Charter of the United Nations. The Charter explicitly recognizes the exercise of self-defence in response to armed attack (Article 51) and authorizes enforcement measures taken or authorized by the Security Council (under chapter "Section VII: Civilians Directly Participating in Hostilities").

4. The OST specifically prohibits the establishment of military bases, installations and fortifications as well as testing of any types of weapons and the conduct of military manoeuvres, on the Moon and other Celestial Bodies.

5. LOAC comprises both customary law and treaties. Customary law generally applies to all States. As far as treaties are concerned, they are binding only upon contracting parties. The reference to applicable principles and rules of LOAC is intended to emphasize that States are bound by different LOAC treaties and by applicable customary law. However, which principles and rules of LOAC apply, and how they apply, may depend, inter alia, on the classification of an act as an attack under LOAC.

\section{Rule 3}

State Parties to the Outer Space Treaty must not place in orbit around the Earth any objects carrying nuclear weapons or any other weapons of mass destruction, install such weapons on the Moon or other Celestial Bodies, or station such weapons in Outer Space in any other manner.

\section{Commentary}

1. This Rule is based on Article IV of the OST which relates to nuclear weapons and other weapons of mass destruction (WMD). The Group of Experts believes that Article IV of the OST today reflects an emerging customary international norm.

2. In order to be considered to be "placed in orbit" an Outer Space object must complete at least one orbit. WMD or nuclear weapons that simply transit through Outer Space without completing an orbit, such as an Intercontinental Ballistic Missile (ICBM), do not fall within the scope of the prohibition.

3. There is no generally accepted definition of WMD. Nuclear Weapons are not defined in international treaties, but according to an Advisory Opinion of the

\footnotetext{
${ }^{6}$ OST, see fn. 2, Preamble.

${ }^{7}$ OST, see fn. 2, Article IV(2).
} 
International Court of Justice they are "explosive devices whose energy results from the fusion or fission of the atom". 8 The Group of Experts took the view that, for the purposes of Article IV (1) of the OST, WMD comprise-in addition to nuclear weapons - those weapons that are prohibited by the 1972 Biological Weapons Convention ${ }^{9}$ and the 1993 Chemical Weapons Convention. ${ }^{10}$

4. An Outer Space object with a nuclear power source is not necessarily a nuclear weapon for the purposes of this Manual.

\section{Rule 4}

Without prejudice to the Charter of the United Nations, the principles and rules of LOAC are the lex specialis during armed conflict and prevail over the general law of Outer Space.

\section{Commentary}

1. The general legal regime applicable in Outer Space, based on customary law as well as applicable treaties, is peacetime law. The OST and other Outer Space treaties are silent as regards the possibility of an armed conflict. ${ }^{11}$ However, LOAC is the lex specialis in the sense that it prevails in situations of armed conflict (either international or non-international) involving Outer Space operations over any inconsistent peacetime norm applicable in Outer Space. That said, LOAC cannot override the Charter of the United Nations.

2. By definition, the principles and rules of LOAC - which apply only in situations of armed conflict-are more specific than the peacetime principles and rules of the law of Outer Space which are lex generalis.

\section{Rule 5}

With respect to an armed conflict, States bear responsibility for their respective internationally wrongful Outer Space operations as well as other wrongful activities conducted in Outer Space that are attributable to them. Responsibility extends to such actions by all persons forming part of the armed forces.

\section{Commentary}

1. This Rule exclusively applies to State responsibility under LOAC. However, the first sentence of the Rule is also consistent with Article VI of the OST.

\footnotetext{
${ }^{8}$ Legality of the Threat or Use of Nuclear Weapons, Advisory Opinion, I.C.J. Reports 1996, p. 226, at para 35, page 243 .

${ }^{9}$ Convention on the Prohibition of the Development, Production and Stockpiling of Bacteriological (Biological) and Toxin Weapons and on Their Destruction (BWC) (1972), UNTS, vol. 1015, page 164 , Article I.

${ }^{10}$ Convention on the Prohibition of the Development, Production, Stockpiling and Use of Chemical Weapons and on their Destruction (CWC) (1993), International Legal Materials (ILM), vol. 32, page 800 , Article II.

${ }^{11}$ See fn. 2 .
} 
2. This is also the general Rule of State responsibility as defined by the International Law Commission, ${ }^{12}$ which are reflective of customary international law. The second sentence of the Rule is based on Article 3 of the 1907 Hague Convention (IV) and Article 91 of the 1977 Protocol I Additional to the Geneva Conventions $(\mathrm{AP} / \mathrm{I}){ }^{13}$

3. It is the view of the Group of Experts that the 1972 Liability Convention does not apply between Belligerent States to an armed conflict. ${ }^{14}$ The Liability Convention does however remain effective between a Belligerent State and Neutral States. See Rule 18.

\section{Rule 6}

A person who wrests control of Outer Space systems and assets assumes responsibility for subsequent use of the system in accordance with the degree and the duration of the control exercised.

\section{Commentary}

1. The Rule refers to the individual responsibility of the person who wrests control of Outer Space systems and assets. Should such a person act on behalf of a State, his/her act will be attributable to that State, which will bear State responsibility.

2. A person who wrests control of an Outer Space system and asset, will bear responsibility for the subsequent use for which the system and asset is put while that individual retains control. However, a question arises as to the allocation of responsibility when the person who wrests control of the system then tranfers that control to another person. There would be potential criminal liability if intent and knowledge could be established.

3. See Commentary to Rule 45.

\section{Rule 7}

(a) In the study, development, acquisition or adoption of a new weapon, means or method of Outer Space warfare, a State that is party to Additional Protocol I must determine whether its employment would,

\footnotetext{
${ }^{12}$ International Law Commission's Draft Articles on Responsibility of States for Internationally Wrongful Acts, Report of the International Law Commission on the work of its fifty-third session, Yearbook of the International Law Commission, 2001, Vol. II, Part Two, page 26, Articles 4 and 5.

${ }^{13}$ Convention IV Respecting the Laws and Customs of War on Land and its Annex: Regulations Respecting the Laws and Customs of War on Land (1907 Hague Regulations) (1907), Schindler and Toman, The Laws of Armed Conflicts, Martinus Nijhoff Publishers (Leiden/Boston) (2004), page 66. Protocol Additional to the Geneva Conventions of 12 August 1949, and Relating to the Protection of Victims of International Armed Conflicts (Protocol I), (AP/I) (1977), The Laws of Armed Conflicts, page 711.

${ }^{14}$ Convention on International Liability for Damage Caused by Space Objects, (Liability Convention) (1972), UNTS, vol. 961, page 187.
} 
in some or all circumstances, be prohibited by any rule of international law applicable to that State.

(b) In the acquisition of a new weapon or means of Outer Space warfare, a State that is not party to Additional Protocol I should determine whether its employment would, in some or all circumstances, be prohibited by applicable principles and rules of LOAC.

\section{Commentary}

1. This Rule is based on Article 36 of AP/I, which is applicable only to Contracting Parties.

2. The provision of Article 36 of AP/I has not yet crystallized as customary international law, and therefore non-contracting Parties are not legally bound to abide by the full extent of its strictures. Some of the non-contracting Parties whose interests are specially affected, while conducting significant weapon review procedures, maintain that this is done as a "best practice" rather than out of a sense of legal obligation. In other words, these countries do not share an opinio juris on an independent obligation to conduct legal reviews of weapons under customary international law.

3. As far as non-contracting Parties to Additional Protocol I are concerned, the practice regarding the adoption of new methods of warfare is less clear than it is with regard to new means of warfare.

4. For its part, the Group of Experts believes that there is an implied rule requiring all States to review the lawfulness of new weapons and means of warfare that they acquire, with a view to avoiding incompatibility with the two basic principles of LOAC, i.e., distinction and the prohibition of unnecessary suffering and superfluous injury.

5. The reference to the development or acquisition of a new means of warfare has to be understood as referring to the planned or intended consequence of that means of warfare in the context of its normal and expected use.

6. Reference to the principles and rules of LOAC does not obviate the need to conform with other norms of international law as and when applicable.

7. It may as well be added that the testing of nuclear weapons in Outer Space is specifically prohibited by the Treaty Banning Nuclear Weapon Tests in the Atmosphere, in Outer Space and Under Water. ${ }^{15}$

\section{Rule 8}

In Outer Space operations occurring during armed conflict, the concept of attack applies to all acts of violence against the adversary, whether in offence or defence. The acts must be intended to cause-or must be reasonably expected to result in-death, injury, destruction or damage. These acts

\footnotetext{
${ }^{15}$ Treaty Banning Nuclear Weapon Tests in the Atmosphere, in Outer Space and Under Water (LTBT) (1963), UNTS, vol. 480, page 44. Articles 1(a) and (b).
} 
generally do not include those intended to cause only temporary loss of functionality, e.g., jamming.

\section{Commentary}

1. The first sentence, which is reflected in AP/I, ${ }^{16}$ is based on customary law.

2. The notion of "attack" under this Rule must not be confused with jus ad bellum rules under the Charter of the United Nations.

3. The second sentence defines the term "acts of violence". Accordingly, the intentional destruction of an Outer Space object or the intentional infliction of any physical damage to it will be an attack under this Rule. Acts that are not intended to result in such consequences do not qualify as attacks.

4. "Acts of violence against the adversary" include acts against combatants or civilians, military objectives or civilian objects.

5. During military operations in armed conflict, many acts may be understood to have some causal connection to death, injury, destruction, or damage. Acts in support of military operations (e.g., refuelling military aircraft), accidents, or other acts that simply bear some causal connection to death, injury, destruction, or damage are not, by that causal connection, automatically considered attacks.

6. Nonetheless, where it is reasonably expected that the direct and ordinary consequence of an action is to cause death, injury, destruction or damage, such action could, depending on the circumstances, be regarded as "intentional" thus qualifying the action as an attack and thereby triggering the legal obligations that attach to "attacks" under LOAC.

7. Causing temporary loss of functionality, which could either be brief or prolonged - in and of itself-does not constitute an attack inasmuch as it usually does not cause death, injury, damage or destruction. However, in Outer Space, causing a temporary loss of functionality may in certain circumstances be intended to cause death, injury, destruction or damage, and would thus constitute an attack. For example, the temporary degradation of space assets', navigation functionality could be used intentionally to cause the crash of those assets. Conversely, temporary degradation resulting in only temporary consequences, such as temporary loss of communication, would not per se constitute an attack.

8. "Shadowing" of a satellite, which means depriving it of solar energy supply through positioning another object in between the satellite and the sun, does not necessarily constitute an attack. In the context of the present Rule and as regards what constitutes damage, there are divergent views. Some have said that damage must be limited specifically to a situation in which physical repairs are required, whereas others would contend that reduced or extinguished functionality would be sufficient.

${ }^{16} \mathrm{AP} / \mathrm{I}$, see fn. 13 , Article 49. 
9. Similarly, "blinding" a satellite sensor by targeting it with a laser (and causing no physical damage to the satellite, but temporarily preventing its proper functioning), does not necessarily qualify as an attack.

10. Jamming, like the blinding of a sattelite, is a form of temporary loss of functionality. It should be noted, however, that jamming may be a constitutive component of an overall attack.

\section{Rule 9}

In principle, Outer Space systems and assets belonging to the armed forces constitute military objectives because, by nature, they make an effective contribution to the enemy's military action.

\section{Commentary}

1. Military objectives by nature are defined in chapter "Section IX: Military Objectives by Nature", Rules $77 \mathrm{ff}$.

2. Military objectives by nature are lawful targets at all times and in all circumstances during an armed conflict.

3. The words "in principle" were included to clarify that this was a general rule subject to exceptions. For example, medical aid stations in Outer Space belonging to the military would be excluded.

4. Outer Space systems and assets belonging to the armed forces may include, e.g.: military satellites performing telecommunication, Earth Observation (EO), early warning, weather observation, navigation, and Intelligence, Surveillance and Reconnaissance (ISR) functions. See commentary to Rule 1 (d).

5. Since infrastructure components may be located in a Neutral State, additional considerations apply, see Rules 18-19 and Commentary.

\section{Rule 10}

Civilian Outer Space systems and assets must not be the object of attack unless they qualify as military objectives—if not by nature-by location, purpose or use.

\section{Commentary}

1. Civilian objects are protected against direct attack according to customary LOAC. This is also the rule under Article 52(1) of AP/I. Ex hypothesi, civilian objects are not military objectives.

2. Civilian space systems include satellites and all related ground infrastructure that cannot be classified as a military objective according to Rule 9 .

3. Civilian space systems will nevertheless become lawful targets if by location, purpose or use they make an effective contribution to military action, and if their total or partial destruction or neutralization, in the circumstances ruling at the time offers a definite military advantage. 
4. Examples of purpose or use rendering civilian Outer Space systems and assets lawful targets are:

a. Commercial space systems used to augment military space capabilities and to increase the resiliency of space architectures, e.g., space launch facilities.

b. Communication satellites or commercial earth-imaging systems normally used for civilian purposes but effectively contributing to military action, e.g., GPS satellite systems and EO satellites used for military Command and Control functions or intelligence collection.

c. Satellites hosting a military payload (dual use).

\section{Rule 11}

In Outer Space operations constituting attacks, assessments of collateral damage should take into consideration the effects of space debris expected to result from the attack.

\section{Commentary}

1. Rule 11 reflects unique Outer Space considerations regarding the proportionality rule as established by treaty and customary LOAC prohibiting attacks that may be "expected to cause incidental loss of civilian life, injury to civilians, damage to civilian objects, or a combination thereof, which would be excessive in relation to the concrete and direct military advantage anticipated."17 "Collateral damage" is the common term for "incidental loss of civilian life, injury to civilians, damage to civilian objects, or a combination thereof", as expressed in Article 51(5)(b) of AP/I.

2. The fact that space debris can be expected to result from a kinetic attack in Outer Space does not in itself render the attack unlawful, but it may play a significant role in the assessment of collateral damage. ${ }^{18}$

3. Due to the particular nature of Outer Space, the debris expected to result from an attack or the effects of an electromagnetic pulse (EMP), could easily affect civilian satellites, or damage or destroy the Outer Space assets of the attacking Party itself.

4. The outcome of the proportionality assessment may depend upon the orbit where the attack occurs. For example, the effects of an attack by a Kinetic Anti-Satellite (K-ASAT) Weapon in the geostationary orbit could be particularly serious.

5. An attack upon an Outer Space system or asset may be expected to result in damage to or destruction of satellites not constituting military objectives.

\footnotetext{
${ }^{17} \mathrm{AP} / \mathrm{I}$, see fn. 13, Article 51(5)(b).

${ }^{18}$ Space debris may be defined as all man-made objects, including fragments and elements thereof, in Earth orbit or re-entering the atmosphere, that are non-functional. See Space Debris Mitigation Guidelines of the Committee on the Peaceful Uses of Outer Space, endorsed by the UN Committee on the Peaceful Uses of Outer Space at its fiftieth session and contained in A/62/20, annex.
} 
Moreover, an attack may result in the denial of the exercise of the right to use Outer Space by civilian satellites or seriously damage crucial civilian infrastructures that depend upon Outer Space systems in order to function properly. Such expected consequences must be considered in relation to the concrete and direct military advantage anticipated when applying the proportionality rule.

6. Collateral damage does not include mere inconvenience. However, if as a result of the presence of debris in Outer Space a civilian satellite is forced to detour, thereby expending fuel so as to be unable to perform its normal functions, the situation may no longer amount to mere inconvenience.

\section{Rule 12}

The concept of direct participation in hostilities applies to civilians, including civilian employees of State agencies, who conduct Outer Space operations in the context of an armed conflict.

\section{Commentary}

1. The concept of direct participation in hostilities (DPH) is firmly established in treaty and customary LOAC and is expressed in Article 51(3) of AP/I, as well as common Article 3 to the four Geneva Conventions and Article 13(3) of AP/II applicable in non-international armed conflicts. ${ }^{19}$ In accordance with this concept, civilians enjoy protection from attack "unless and for such time as they take a direct part in hostilities."

2. This Rule is without prejudice to the question whether a certain activity actually qualifies as DPH.

3. See chapters "Section VII: Civilians Directly Participating in Hostilities" and "Section VIII: Civilians Participating in Unmanned Operations".

\section{Rule 13 \\ In Outer Space operations, activities qualifying as direct participation in hostilities may include:}

(a) Any activity designed or intended to directly cause death of, injury to, damage to or destruction of to an adverse party;

\footnotetext{
${ }^{19}$ Protocol Additional to the Geneva Conventions of 12 August 1949, and Relating to the Protection of Victims of Non-International Armed Conflicts (Protocol II) (AP/II) (1977), Laws of Armed Conflicts, page 775, at page 781. Common Article 3 appears in the following: Convention (I) for the Amelioration of the Condition of the Wounded and Sick in Armed Forces in the Field (GC I) (1949), Laws of Armed Conflict, page 459, at page 461; Convention (II) for the Amelioration of the Condition of the Wounded, Sick and Shipwrecked Members of Armed Forces at Sea (GC II) (1949), Laws of Armed Conflict, page 485, at page 487; Convention (III) relative to the Treatment of Prisoners of War (GC III) (1949), Laws of Armed Conflict, page 507, at page 512; Convention (IV) Relative to the Protection of Civilian Persons in Time of War (GC IV), Laws of Armed Conflict, page 575 , at page 580 .
} 
(b) Defence of military space objects against enemy attacks;

(c) Contributing to targeting procedures, such as helping to identify or prioritize targets;

(d) Engaging in planning specific attacks;

(e) Military reconnaissance or surveillance; or

(f) Operating a tactical communications relay.

\section{Commentary}

1. The entire issue of definition of activities amounting to DPH is subject to controversy and disagreement among experts. This Manual focuses on examples on which consensus could be reached.

2. This Rule too is without prejudice to the question whether a certain activity actually qualifies as DPH. On the notion of DPH, see chapter "Section VII: Civilians Directly Participating in Hostilities".

\section{Rule 14}

In Outer Space operations constituting attacks, feasible precautions should be taken with a view to the specific characteristics of Outer Space, including the presence or functions of civilian satellites and the effects on the use of the electromagnetic spectrum.

\section{Commentary}

1. The duty to take feasible precautions in attack is customary in nature and is reflected in Article 57 of AP/I. "Feasible precautions" are those that are practicable or practically possible, taking into account all circumstances ruling at the time, including humanitarian and military considerations. In particular, Belligerent States should verify that the target is a military objective and minimize collateral damage. When feasible, attacks must be cancelled or suspended if decision-makers learn that the object is not a military objective or if the attack may be expected to violate the proportionality rule.

2. When alternative targets of attack present themselves, the legal position as far as Contracting Parties to AP/I are concerned is that-among targets offering similar military advantage - they must select the one where collateral damage would be minimized. As far as non-contracting parties to AP/I are concerned, the obligation to minimize collateral damage in attack may be understood as applying only to targets offering the same military advantage.

3. Effective advance warning of attacks likely to affect the civilian population must be provided, unless circumstances do not permit.

4. Verification that a target is a military objective should take into account that civilian communications satellites often are placed in crowded orbits such as the geostationary orbit and that they may be controlled by a multitude of owners and third-party providers of services, in a variety of jurisdictions. 
5. Commercial communication satellites usually have a capacity based on a multitude of transponders, where capacity, not transponders, is sold or leased to a multitude of clients. Military use of any such capacity renders that satellite a military objective. The fact that the use of the remaining capacity is civilian in nature does not affect the characterization of the satellite, but may raise proportionality issues.

6. The electromagnetic spectrum is defined in paragraph 3 of the Commentary to Rule 1(c) and is the medium for providing satellite-information and services to the Earth. Feasible precautions should be taken in order to reduce the extent of harmful effects on space capabilities that do not constitute military objectives.

7. The requirement to take precautions in attack necessitates assessment of the impact of space debris. It also might involve consideration of the effects on the use of the electromagnetic spectrum. The assessment includes efforts to assess the likelihood of civilian satellites being struck by debris (see Rule 11) and a consideration of limitations on the manoeuvre capabilities of Outer Space vehicles to the extent that this amounts to damage as distinct from mere inconvenience. It may also be appropriate to assess the effect of an energized atmosphere or scintillated ionosphere upon space communications and may require determination of the likelihood of interference or damage to be caused to a given signal, satellite, line of communication or ground asset by the effects on the electromagnetic environment.

8. If an Outer Space system or asset controlled by a Neutral State qualifies as a lawful target, additional considerations apply. See Rule 18 with Commentaries.

\section{Rule 15}

The AP/1 obligations with regard to the natural environment should apply to Outer Space operations and to their effects on all parts of Outer Space, the Moon and other Celestial Bodies.

\section{Commentary}

1. The provision of Article 35 (3) AP/1 protects the natural environment against attacks that are expected or intended to cause widespread, long-term and severe damage. This provision does not apply to Outer Space. However, the Group of Experts agreed that in the conduct of Outer Space operations the same principle should be applied by analogy.

2. For the meaning of the AP/1 prohibition, see the Commentary on Rule 140.

3. For an illustration relating to Outer Space, consider the irradiation of areas of Outer Space protected by the Van Allen belts through nuclear explosions.

\section{Rule 16}

States Parties to the ENMOD Convention are prohibited from making any military or other hostile use of Outer Space environmental modification 
techniques having widespread, long-lasting or severe effects as the means of destruction, damage or injury to any other State Party.

\section{Commentary}

1. Because the ENMOD Convention ${ }^{20}$ does not express customary LOAC, its obligations only bind States Parties to the Convention. The ENMOD Convention specifically prohibits the use of environmental modification techniques on the "lithosphere, hydrosphere and atmosphere, or of Outer Space."

\section{Rule 17}

(a) Enemy Outer Space systems and assets, in theory, could be subject to capture as prize.

(b) Enemy character can be determined by registration, ownership, charter, control, or other criteria.

(c) Neutral Outer Space systems and assets may not be captured as prize, unless they are used for rendering unneutral service.

\section{Commentary}

1. Subject to Rule 3, the LOAC right to capture of enemy Outer Space systems and assets prevails over the duty to recover and return space objects in the Rescue Agreement, Article 5. ${ }^{21}$

2. The use of "in theory" is intended to convey that the Group of Experts was not aware of State practice in subjecting space systems and assets to prize law. Moreover, capture of an object in orbit may be impractical under present technology.

3. The enemy character of an Outer Space system or asset is not necessarily the same as its "State of registry" according to the Registration treaty. ${ }^{22}$

4. In theory, rendering unneutral service would make neutral Outer Space systems and assets liable to be captured as prize. However, many of the services that are today provided by satellites (such as providing satellite imagery for military use) could, if provided to a Belligerent Party, render the satellite a lawful military objective rather than merely subjecting it to capture.

\footnotetext{
${ }^{20}$ Convention on the Prohibition of Military or any Hostile use of Environmental Modification Techniques (ENMOD) (1976), UNTS, vol. 1108, page 151.

${ }^{21}$ Agreement on the Rescue of Astronauts, the Return of Astronauts and Return of Objects Launched into Outer Space (1968), UNTS, vol. 672, page 119.

${ }^{22}$ Convention on Registration of Objects Launched into Outer Space (1974), UNTS, vol. 1023, page 15, Article 1(c).
} 


\section{Rule 18}

As a general principle, neutral States must not knowingly allow space systems and assets for which they are responsible to be used by Belligerent States in Outer Space operations related to armed conflict.

\section{Commentary}

1. The concept of neutrality, applicable to a State which is not a Belligerent Party in a given international armed conflict, relates to the conduct of hostilities in all circumstances and therefore extends to Outer Space operations. This is particularly important as regards the obligation of the Neutral State to maintain its impartiality in the armed conflict.

2. Given that the law of neutrality relies heavily on the concept of "neutral territory", some aspects of that law may be inconsistent with the characteristic of Outer Space. The Group of Experts believe however, that the law of neutrality may be applied in the context of Outer Space mutatis mutandis.

3. There is substantive treaty law as well as customary law with respect to the standing of a Neutral State in an armed conflict. However, neither the treaty law nor customary law pertains to Outer Space as such. Hence, any application of existing rules in an Outer Space context can only be based on analogy.

4. This Rule reflects the principles of the customary law of neutrality (as expressed, inter alia, in the 1907 Hague Convention V on Neutral Powers and Persons in War on Land and the 1907 Hague Convention XIII on Neutrality in Naval $\mathrm{War}^{23}$ ).

5. Belligerent States are forbidden from erecting on the territory of a Neutral State any military ground infrastructure intended to be used in the armed conflict. This general prohibition also applies to communication installations for satellites operated by Belligerent armed forces.

6. The prohibition extends to the exclusively military use of such installations, established before the armed conflict on the territory of a Neutral State. ${ }^{24}$

7. The employment on neutral territory of ground station functions such as TT\&C (see paragraph 5 of the Commentary to Rule 9) used for communication between a spacecraft and ground systems for the execution of belligerent acts is a violation of neutrality. However, the simple downloading of data from a civilian satellite by ground stations on neutral territory does not violate neutrality when the activity is not linked to the hostilities.

8. A Neutral State may not launch military satellites on behalf of a Belligerent Party. Nor may it provide any services to a Belligerent Party military satellite already in orbit.

\footnotetext{
${ }^{23}$ Convention (V) Respecting the Rights and Duties of Neutral Powers and Persons in Case of War on Land (1907), Laws of Armed Conflicts, page 1399. Convention (XIII) Concerning the Rights and Duties of Neutral Powers in Naval War (1907), Laws of Armed Conflicts, page 1407.

${ }^{24}$ For comparative purposes, see Article 3 of the 1907 Hague Convention (V) on Neutral Powers and Persons in War on Land, see fn. 23.
} 
9. A Neutral State may not sell or otherwise transfer a satellite for military uses by a Belligerent Party.

10. However, commercial and trade activities by neutral companies or individuals with a Belligerent State are not prohibited.

11. The use by a Belligerent State of telecommunication satellites owned by or under the exclusive control of a Neutral State is not a violation of neutrality. A Neutral State has no obligation to prevent the use of its telecommunication satellites by a Belligerent State to the conflict which had access to the satellite prior to the outbreak of hostilities. ${ }^{25}$

12. Existing non-military telecommunications satellites owned by private companies or individuals may be used by Belligerent Parties, e.g., by renting satellite transponder capacity for voice and data communication of a military nature.

13. Restrictions imposed by a Neutral State on the belligerent use of privately owned telecommunication satellites, must be impartially applied to both (all) Belligerent Parties. ${ }^{26}$

14. The necessary use of force by a Neutral State to prevent its Outer Space assets from being used by a Belligerent State to commit a belligerent act is not a violation of neutrality. $^{27}$

15. This Rule is without prejudice to Rules 9 and 10 and the definition of military objectives.

\section{Rule 19}

\section{As a general principle, Belligerent States must conduct their Outer Space operations with due regard for the rights of Neutral States.}

\section{Commentary}

1. There is an obligation incumbent on Belligerent States to act with due regard for the rights of Neutral States to use Outer Space. ${ }^{28}$

2. In the planning of Outer Space operations, Belligerent States should implement measures in order to reduce the risk of damaging neutral critical infrastructure and communication space assets. $^{29}$

\footnotetext{
${ }^{25} 1907$ Hague Convention (V) on Neutral Powers and Persons in War on Land, ibid, Article 8.

${ }^{26} 1907$ Hague Convention (V) on Neutral Powers and Persons in War on Land, ibid, Article 9.

${ }^{27} 1907$ Hague Convention (V) on Neutral Powers and Persons in War on Land, ibid, Article 10.

${ }^{28}$ OST, see fn. 2, Article IX.

${ }^{29}$ Similar duties are established in naval warfare. See San Remo Manual on International Law Applicable to Armed Conflicts at Sea (San Remo Manual) (1994), The Laws of Armed Conflicts, page 1153 , paras 12 and 88 .
} 
Open Access This chapter is licensed under the terms of the Creative Commons Attribution 4.0 International License (http://creativecommons.org/licenses/by/4.0/), which permits use, sharing, adaptation, distribution and reproduction in any medium or format, as long as you give appropriate credit to the original author(s) and the source, provide a link to the Creative Commons licence and indicate if changes were made.

The images or other third party material in this chapter are included in the chapter's Creative Commons licence, unless indicated otherwise in a credit line to the material. If material is not included in the chapter's Creative Commons licence and your intended use is not permitted by statutory regulation or exceeds the permitted use, you will need to obtain permission directly from the copyright holder. 